\title{
Expert System Diagnosing Anxiety Disorder Using Based Naïve Bayes Method
}

\author{
Danvy Nadhira, Fristi Riandari,
}

Informatics Engineering, STMIK Pelita Nusantara, Sumatera Utara, Indonesia

\section{Article Info}

Article history:

Received: 29/09/2021

Revised: $17 / 10 / 2021$

Accepted: 05/11/2021

Available online 01/12/2021

\section{Keywords:}

Anxiety Disorder, Naïve Bayes, Expert System, WEB

\begin{abstract}
Psychological problems such as Anxiety Disorder have become a common problem in the world. Most sufferers of this disease are under 45 years old on average and usually this disorder often attacks the mentality of women. However, this disease is often considered trivial and not many sufferers realize it. Not to mention the handling of course requires quite a lot of money. Another thing is the lack of information about this disease, which causes the risk of sufferers of Anxiety Disorder to increase every year. To solve existing problems, it can be solved by using computer technology in the health sector that can diagnose a disease like an expert, namely an expert system application disease symptoms. The purpose of this study is as a first step to treat this disorder as quickly as possible. The application of the Naïve Bayes method plays a role in being able to provide diagnostic results because the Naïve Bayes method is considered capable of providing the largest clarification of the value of $\mathrm{v}$ based on the selected symptoms.
\end{abstract}

This is an open access article under the CC BY-NC license.

\section{Corresponding Author:}

Fristi Riandari,

Informatics Engineering,

STMIK Pelita Nusantara Medan,

Jl Iskandar Muda No. 1 Medan, 20154, Indonesia.

Email: fristy.rianda@ymail.com

\section{Introduction}

The development of computer technology has had an important impact on all fields. This has resulted in almost all work activities involving computers. The involvement of today's computer technology can certainly solve community problems in the form of a limited scope to leave the house during the COVID-19 pandemic to check with an expert, not to mention the limited cost which is a big obstacle for the community during the pandemic because many workers have been laid off. . With its technology, computers can help humans in solving a problem in any field, such as in the fields of health, economics and others. One of the developments in computer technology in the health sector is the application of expert systems. An expert system is a system that is able to solve problems like an expert or expert.

These problems can be solved by using an expert system application, where the analysis approach uses the Naive Bayes method. The Naïve Bayes method is a clarification of the probability and statistical methods proposed by the British scientist Thomas Bayes, where this method is based on previous experience, namely estimating future possibilities. The Naive Bayes method is also considered to have good potential in clarifying documents compared to other clarification methods in terms of accuracy and computational efficiency [1]. 
One of the mental illnesses that is often taken for granted is Anxiety Disorder. If this disease is ignored, it will cause the sufferer to have difficulty in activities. In addition, if this disease is continuously ignored, it will cause systemic complications that lead to death for the sufferer. Now the highest number of people with mental disorders is more than 8.4 million people, this number is the highest case in Southeast Asia, namely in Indonesia. Even WHO states that Anxiety is a mental disorder whose prevalence is increasing every year [2].

The purpose of this study is to produce information in diagnosing the symptoms of a disease experienced by the sufferer.

In the same study by [3] with the study of Diagnosing Anxiety Disorders Using the Certainty Factor Method in this study there were 3 types of diseases while for symptom data there were 14 symptoms of the disease and had the results of percentage calculations. Then in research [4] entitled Expert System for Early Detection of Anxiety Disorders Using the Web-Based Forward Chaining Method where this study diagnosed 15 disease data and 16 symptom data and for the design results were designed using a rule base in the form of the Forward Chaining inference method. Another study related to Anxiety Disorder [5] entitled Implementation of the Forward Chaining Method in an Anxiety Disorder Diagnosing Expert System with the results of an expert system using the forward chaining inference method, with 5 types of disease samples and 44 symptoms. In another previous study with the title Expert System for Diagnosing Anxiety Disorders Using the Android-Based Forward Chaining Method [6] where the study used 23 total symptoms and the inference method was the forward chaining method. Then in another study by [7] in his research related to Detection of Obsessive Compulsive Disorder Anxiety Disorders there were 3 clarifications of OCD anxiety disorder, 20 symptoms, then in this study only examined one type of anxiety disorder and the diagnosis results in the form of the density value of $81 \%$. And in the same study with the title But in this study the diagnosis of Anxiety Disorder (anxiety disorders) uses disease data as many as 6 types of Anxiety Disorders and 30 symptoms and their solutions. In designing the system to determine the diagnostic results, this study applies the Naïve Bayes method, which is considered to have a fairly good accuracy value to clarify the diagnosis of a disease.

\section{Method}

\subsection{Research Framework}

This research method consists of a research framework, which is a description of how it works and the steps for conducting research, while the framework of this research includes: 


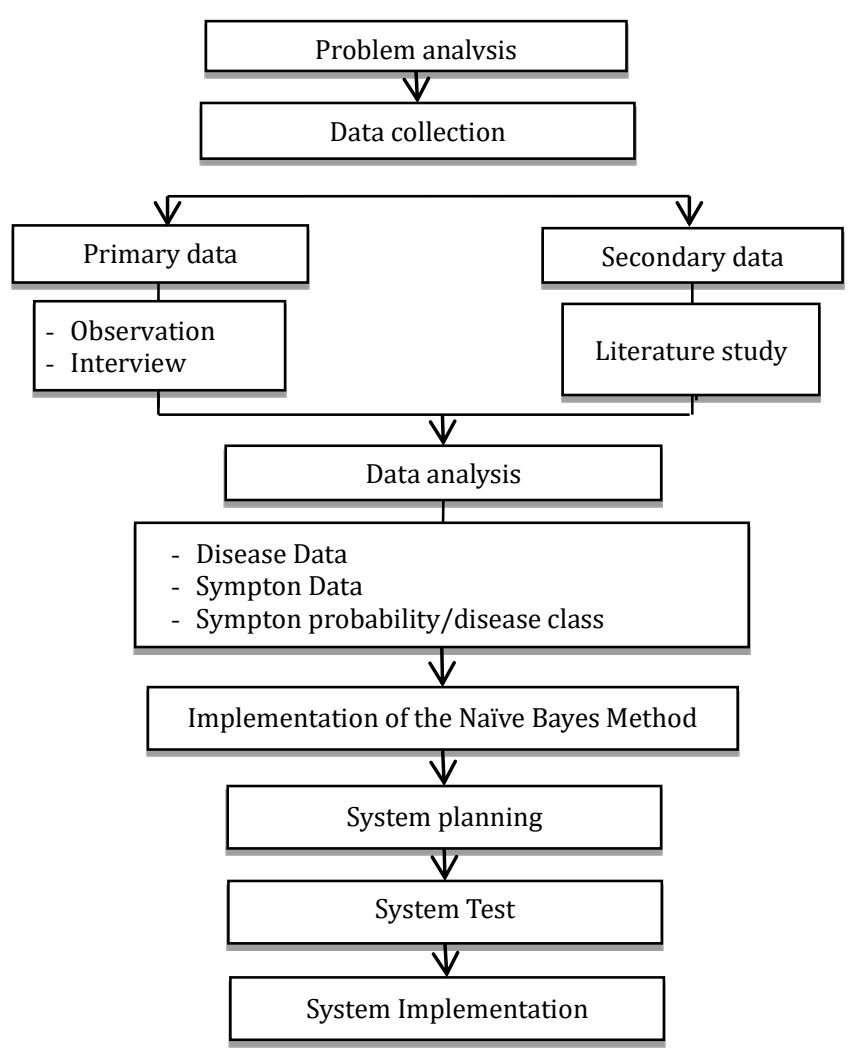

Figure 1. Research Framework

a. Problem analysis

The first stage is problem analysis, problem analysis in this study is in the form of problems that occur in the lack of knowledge about Anxiety Disorder and diagnose this disease without having to go to the experts.

b. Data collection

The second stage is data collection, where there are two techniques in data collection, namely primary data and secondary data, namely:

1). Primary data is in the form of observation, namely data collection which is carried out by direct observation at the Sultan Sulaiman Regional General Hospital, which is located at Jl. Negara KM 58 No.315, Firdaus, Kec. Sei Rampah, Serdang Bedagai Regency, North Sumatra 20995.

2). Primary data in the form of interviews conducted with the resource person, namely dr. Endah Tri Lestari, M.Ked, Sp.KJ.

3). Secondary data is in the form of literature studies, namely collecting data from several books, several journals and also internet sources.

c. Data analysis

The third stage of data analysis, in this study, is to choose any data obtained from the results of data collection such as disease data, symptom data and symptom probability between disease classes.

d. Implementation of the Naïve Bayes Method

The fourth stage at this stage is to carry out a test action on the data to be processed using the Naïve Bayes method that has been implemented. The Naïve Bayes method is a clarification with the probability and statistical methods proposed by the British scientist Thomas Bayes, which predicts future opportunities based on previous experiences [1].

The formula for implementing Naïve Bayes is: 
e. System planning

$$
\mathrm{P}(\mathrm{Gi} \mid \mathrm{vj})=\frac{n_{c}+m \cdot p}{n+m}
$$

The fifth stage of system design in this study using programming languages, namely PHP and HTML, for the database using MySQL and XAMPP. Because the expert system diagnoses Anxiety disorder which is designed on a web-based basis.

f. System Test

The sixth stage at this stage the system that was built will be tested. System testing is a process in terms of trying and finding out whether the expert system in diagnosing Anxiety Disorder using the Naïve Bayes method is indeed feasible or in accordance with what is expected. This test is carried out in order to find out the weaknesses and advantages of the system that was built.

g. System Implementation

The seventh stage which is the last stage of system implementation is the step made in completing the design in a system in accordance with the design that has been built and has been agreed upon.

\section{Result and Discussion}

In designing this expert system by taking sources from experts or doctors, books and journals. This design will be web-based which is useful for detecting disease using the nave Bayes method.

a. Types of Anxiety Disorder

The table below describes the types of anxiety disorders, which are 6 types of diseases and their disease codes.

TABLE 1.

DATA TYPES OF ANXIETY DISORDER

\begin{tabular}{cl}
\hline Disease Code & Disease \\
\hline P01 & Panic Disorder with Agoraphobia \\
P02 & Panic Disorder without Agoraphobia \\
P03 & Social Phobia Disorder \\
P04 & Generalized Anxiety Disorder \\
P05 & Obsessive-Compulsive Disorder \\
P06 & Post Traumatic Stress Disorder \\
\hline
\end{tabular}

b. Symptoms of Anxiety Disorder

The table below describes the symptoms of anxiety disorder, which totals 30 symptoms of the disease along with their symptom codes.

TABLE 2.

Symptoms of ANXIETY DisoRDER

\begin{tabular}{ll}
\hline Disease Code & Disease Symptoms \\
\hline G01 & Excessive anxiety or worry \\
G02 & Ganic attacks that occur within 1 month or more \\
G04 & Gersistent worry about having another attack \\
G05 & There is agoraGhobia \\
G06 & Losing control \\
G07 & Always feeling restless and thinking unrealistically \\
G08 & ReGeated Ganic attacks \\
G09 & Motor tension (headache) \\
G10 & Nervous \\
G11 & Shaking \\
G12 & Can't relax \\
G13 & Autonomic overactivity (lightheadedness) \\
G14 & Sweating
\end{tabular}




\begin{tabular}{ll}
\hline Disease Code & Disease Symptoms \\
\hline G15 & Hard to breathe \\
G16 & Gastric ComGlaints \\
G17 & Headache \\
G18 & Dry mouth \\
G19 & Anxiety (worried about bad luck) \\
G20 & Anxiety (feeling on edge) \\
G21 & Anxiety (difficulty concentrating) \\
G22 & Recurrent obsessions or comGulsions \\
G23 & There is 1 thought or action that can't be resisted \\
G24 & Fear of being dirty, exGosed to germs or infection \\
G25 & The Gresence of trauma in the memory of an event \\
G26 & Social withdrawal \\
G27 & Gathering of feelings \\
G28 & Hard to sleeG \\
G29 & The duration of the symGtoms is more than one month \\
G30 & Mood disorders \\
\hline
\end{tabular}

c. Rule Base

The rule base for each tyGe of anxiety disorder :

1). Ganic Disorder with AgoraGhobia (G01) : G01, G02, G03, G04, G05, G07, G13, G15, G17, G20

2). Ganic Disorder without AgoraGhobia (G02) : G01, G02, G03, G05, G07, G13, G15, G17, G20

3). Social Ghobia Disorder (G03) : G01, G02, G06, G10, G13, G14, G20

4). Generalized Anxiety Disorder (G04) : G01, G02, G06, G08, G09, G10, G11, G12, G13, G14, G15,

G16, G17, G18, G19, G20, G21

5). Obsessive-ComGulsive Disorder (G05) : G01,G17, G20, G22, G23, G24

6). Gost Traumatic Stress Disorder (G06) : G01, G13, G14, G25, G26, G27, G28, G29, G30

d. ExamGle Case Study of Naïve Bayes method

For examGle, a user (Gatient) has symGtoms of Anxiety Disorder that is being suffered. The calculation using the Naïve Bayes method is as follows:

SymGtom :

G01 = Loss of control

G06 = Always feel restless and think unrealistically

G14 = Heart GalGitations

G21 = Difficulty concentrating

The steGs for calculating naive Bayes are as follows:

1) Determine the value of nc for each class

If a symGtom is a disease class, then nc will be 1 otherwise it will be 0 .

Disease 1 (G01) Ganic Disorder with AgoraGhobia

SymGtom value for each class $(\mathrm{n})=1$

SymGtom value divided by many disease classes $(G)=1 / 6=0.1667$

Total symGtoms $(\mathrm{m})=30$

G01.nc $=1$

$\mathrm{G} 06 . \mathrm{nc}=0$

$\mathrm{G} 14 . \mathrm{nc}=0$

$\mathrm{G} 21 . \mathrm{nc}=0$

Disease 2 (G02) Ganic Disorder without AgoraGhobia

SymGtom value for each class $(\mathrm{n})=1$

SymGtom value divided by many disease classes $(G)=1 / 6=0.1667$

Total symGtoms $(\mathrm{m})=30$

G01.nc $=1$

$\mathrm{G} 06 . \mathrm{nc}=0$

$\mathrm{G} 14 . \mathrm{nc}=0$

$\mathrm{G} 21 . \mathrm{nc}=0$ 
Disease 3 (G03) Social Ghobia Disorder

SymGtom value for each class $(\mathrm{n})=1$

SymGtom value divided by many disease classes $(G)=1 / 6=0.1667$

Total symGtoms $(\mathrm{m})=30$

G01.nc $=1$

G06.nc $=1$

G14.nc $=1$

$\mathrm{G} 21 . \mathrm{nc}=0$

Disease 4 (G04) Generalized Anxiety Disorder

SymGtom value for each class $(\mathrm{n})=1$

SymGtom value divided by many disease classes $(G)=1 / 6=0.1667$

Total symGtoms $(\mathrm{m})=30$

G01.nc $=1$

$\mathrm{G06.nc}=1$

$\mathrm{G} 14 . \mathrm{nc}=1$

$\mathrm{G} 21 . \mathrm{nc}=1$

Disease 5 (G05) Obsessive-ComGulsive Disorder

SymGtom value for each class $(\mathrm{n})=1$

SymGtom value divided by many disease classes $(\mathrm{G})=1 / 6=0.1667$

Total symGtoms $(\mathrm{m})=30$

G01.nc $=1$

$\mathrm{G06} \cdot \mathrm{nc}=0$

$\mathrm{G} 14 . \mathrm{nc}=0$

$\mathrm{G} 21 . \mathrm{nc}=0$

Disease 6 (G06) Gost Traumatic Stress Disorder

SymGtom value for each class $(\mathrm{n})=1$

SymGtom value divided by many disease classes $(G)=1 / 6=0.1667$

Total symGtoms $(\mathrm{m})=30$

G01.nc $=1$

G06.nc $=0$

$\mathrm{G} 14 . \mathrm{nc}=1$

$\mathrm{G} 21 . \mathrm{nc}=0$

2) Calculate the value of $G(a i \mid$ vj) and calculate the value of $G(G j)$

At this stage, the Grobability value of the $\mathrm{i}$-th symGtom to the $\mathrm{j}$-th disease will be calculated. The first steG starts from the disease class. In calculating the Grobability value, we use (ai $\mid v j$ ) and $\mathrm{G}(\mathrm{vj})$ as follows:

1st Anxiety Disorder (G01) Ganic Disorder with AgoraGhobia

$(\mathrm{G} 01 \mid \mathrm{G} 01)=(1+(30 \times 0,1667)) /(1+30)=0,1936$

$(\mathrm{G} 06 \mathrm{G} 01)=(0+(30 \times 0,1667)) /(1+30)=0,1613$

(G14 G01) $=(0+(30 \times 0,1667)) /(1+30)=0,1613$

$(\mathrm{G} 21 \mathrm{G} 01)=(0+(30 \times 0,1667)) /(1+30)=0,1613$

2nd Anxiety Disorder (G02) Ganic Disorder without AgoraGhobia

(G01 $\mathrm{G02})=(1+(30 \mathrm{x} 0,1667)) /(1+30)=0,1936$

$($ G06 G02 $)=(0+(30 \times 0,1667)) /(1+30)=0,1613$

(G14 G02) $=(0+(30 \times 0,1667)) /(1+30)=0,1613$

$(\mathrm{G} 21 \mathrm{G} 02)=(0+(30 \mathrm{x} 0,1667)) /(1+30)=0,1613$

3rd Anxiety Disorder (G03) Social Ghobia Disorder

$(\mathrm{G} 01 \mid \mathrm{G} 03)=(1+(30 \mathrm{x} 0,1667)) /(1+30)=0,1936$

(G06 G03) $=(1+(30 \times 0,1667)) /(1+30)=0,1936$

(G14 G03) $=(1+(30 \times 0,1667)) /(1+30)=0,1936$

$(\mathrm{G} 21 \mathrm{G} 03)=(0+(30 \times 0,1667)) /(1+30)=0,1613$

4th Anxiety Disorder (G04) Generalized Anxiety Disorder

$(\mathrm{G} 01 \mid \mathrm{G} 04)=(0+(30 \mathrm{x} 0,1667)) /(1+30)=0,1936$ 
\begin{tabular}{l|l|l}
$($ G06 & G04 $)=(1+(30 \times 0,1667)) /(1+30)=0,1936$ \\
(G14 & G04) $=(1+(30 \times 0,1667)) /(1+30)=0,1936$ \\
(G21 & G04) $=(1+(30 \times 0,1667)) /(1+30)=0,1936$
\end{tabular}

5 th Anxiety Disorder (G05) Obsessive-ComGulsive Disorder

$(\mathrm{G01}$ G05) $=(0+(30 \times 0,1667)) /(1+30)=0,1936$

(G06 G05) $=(0+(30 \times 0,1667)) /(1+30)=0,1613$

$(\mathrm{G} 14 \mathrm{G} 05)=(0+(30 \mathrm{x} 0,1667)) /(1+30)=0,1613$

$(\mathrm{G} 21 \mathrm{G} 05)=(0+(30 \times 0,1667)) /(1+30)=0,1613$

6th Anxiety Disorder (G06) Gost Traumatic Stress Disorder

$(\mathrm{G} 01 \mid \mathrm{G} 01)=(0+(30 \times 0,1667)) /(1+30)=0,1936$

$(\mathrm{G} 06 \mathrm{G} 01)=(1+(30 \times 0,1667)) /(1+30)=0,1613$

$(\mathrm{G} 14 \mathrm{G} 01)=(1+(30 \times 0,1667)) /(1+30)=0,1936$

$(\mathrm{G} 21 \mathrm{G} 01)=(0+(30 \mathrm{x} 0,1667)) /(1+30)=0,1613$

3) Calculate $G(a i \mid v j) \times G(v j)$ for each class $v$

1st Anxiety Disorder (G01) Ganic Disorder with AgoraGhobia

$=[\mathrm{G}(\mathrm{G} 01) \times[\mathrm{G}(\mathrm{G} 01 \mid \mathrm{G} 01) \times \mathrm{G}(\mathrm{G} 06 \mid \mathrm{G} 01) \times \mathrm{G}(\mathrm{G} 14 \mid \mathrm{G} 01) \times \mathrm{G}(\mathrm{G} 21 \mid \mathrm{G} 01)$

$=0,1667 \times 0,1936 \times 0,1613 \times 0,1613 \times 0,1613$

$=0,00013544$

2nd Anxiety Disorder (G02) Ganic Disorder without AgoraGhobia

$=[\mathrm{G}(\mathrm{G} 02) \times[\mathrm{G}(\mathrm{G} 01 \mid \mathrm{G} 02) \times \mathrm{G}(\mathrm{G} 06 \mid \mathrm{G} 02) \times \mathrm{G}(\mathrm{G} 14 \mid \mathrm{G} 02) \times \mathrm{G}(\mathrm{G} 21 \mid \mathrm{G} 02)$

$=0,1667 \times 0,1936 \times 0,1613 \times 0,1613 \times 0,1613$

$=0,00013544$

3rd Anxiety Disorder (G03) Social Ghobia Disorder

$=[\mathrm{G}(\mathrm{G} 03) \times[\mathrm{G}(\mathrm{G} 01 \mid \mathrm{G} 03) \times \mathrm{G}(\mathrm{G} 06 \mid \mathrm{G} 03) \times \mathrm{G}(\mathrm{G} 14 \mid \mathrm{G} 03) \times \mathrm{G}(\mathrm{G} 21 \mid \mathrm{G} 03)$

$=0,1667 \times 0,1936 \times 0,1936 \times 0,1936 \times 0,1613$

$=0,00019511$

4th Anxiety Disorder (G04) Generalized Anxiety Disorder

$=[\mathrm{G}(\mathrm{G} 04) \times[\mathrm{G}(\mathrm{G} 01 \mid \mathrm{G} 04) \times \mathrm{G}(\mathrm{G} 06 \mid \mathrm{G} 04) \times \mathrm{G}(\mathrm{G} 14 \mid \mathrm{G} 04) \times \mathrm{G}(\mathrm{G} 21 \mid \mathrm{G} 04)$

$=0,1667 \times 0,1936 \times 0,1936 \times 0,1936 \times 0,1936$

$=0,00023418$

5th Anxiety Disorder (G05) Obsessive-ComGulsive Disorder

$=[\mathrm{G}(\mathrm{G} 05) \times[\mathrm{G}(\mathrm{G} 01 \mid \mathrm{G} 05) \times \mathrm{G}(\mathrm{G} 06 \mid \mathrm{G} 05) \times \mathrm{G}(\mathrm{G} 14 \mid \mathrm{G} 05) \times \mathrm{G}(\mathrm{G} 21 \mid \mathrm{G} 05)$

$=0,1667 \times 0,1936 \times 0,1613 \times 0,1613 \times 0,1613$

$=0,00013544$

6th Anxiety Disorder (G06) Gost Traumatic Stress Disorder

$=[\mathrm{G}(\mathrm{G} 06) \times[\mathrm{G}(\mathrm{G} 01 \mid \mathrm{G} 06) \times \mathrm{G}(\mathrm{G} 06 \mid \mathrm{G} 06) \times \mathrm{G}(\mathrm{G} 14 \mid \mathrm{G} 06) \times \mathrm{x}(\mathrm{G} 21 \mid \mathrm{G} 06)$

$=0,1667 \times 0,1936 \times 0,1613 \times 0,1936 \times 0,1613$

$=0,00016256$

4) Determine the result of the clarification value, namely the value of $v$ which has the largest multiGlication value.

$\mathrm{G} 01=0,00013544 \times 100 \%=0,013544 \%$

$\mathrm{G} 02=0,00013544 \times 100 \%=0,013544 \%$

$\mathrm{G} 03=0,00019511 \times 100 \%=0,019511 \%$

$\mathrm{G} 04=0,00023418 \times 100 \%=0,023418 \%$

$\mathrm{G} 05=0,00013544 \times 100 \%=0,013544 \%$

$\mathrm{G} 06=0,00016256 \times 100 \%=0,016256 \%$

TABLE 3.

CLARIFICATION RESULT OF LARGEST VALUE

\begin{tabular}{lll}
\hline Disease Code & Disease & Value \\
\hline G01 & Ganic Disorder with AgoraGhobia & $0,013544 \%$ \\
G02 & Ganic Disorder without AgoraGhobia & $0,013544 \%$ \\
G03 & Social Ghobia Disorder & $0,019511 \%$
\end{tabular}




\begin{tabular}{lll}
\hline Disease Code & Disease & Value \\
\hline G04 & Generalized Anxiety Disorder & $0,023418 \%$ \\
G05 & Obsessive-ComGulsive Disorder & $0,013544 \%$ \\
G06 & Gost Traumatic Stress Disorder & $0,016256 \%$ \\
\hline
\end{tabular}

\section{Conclusion}

Based on the research that has been done on the system for diagnosing anxiety disorders, it can be concluded that, with the construction of this system, it can certainly help the community and provide convenience for early diagnosis of anxiety disorders based on the symptoms that exist in the system. The expert system using the Naïve Bayes method works by entering symptoms and performing Nave Bayes calculations. And the results of disease diagnosis in this system are based on the largest $\mathrm{V}$ value. This expert system with the Naïve Bayes method is designed and built based on a web that has a main page menu, login menu, disease data menu, data symptom menu, data rules menu, training data menu, diagnostic data menu, user data menu, profile menu, consultation menu, diagnostic menu for users. The way the diagnosis works is of course using the Naïve Bayes method which is able to provide diagnostic results.

\section{References}

[1] R. H. Restari, S. Sinurat, and S. Suginam, "Rancangan Aplikasi Sistem Pakar Diagnosa Penyakit Mononukleosis Dengan Metode Naive Bayes," JURIKOM (Jurnal Ris. Komputer), vol. 7, no. 3, p. 403, 2020, doi: $10.30865 /$ jurikom.v7i3.2179.

[2] N. S. Lataima, F. Keperawatan, and U. Airlangga, “DOI: http://dx.doi.org/10.33846/sf11204 Manfaat," vol. 11, no. April, pp. 129-132, 2020.

[3] H. Suhendi and A. Supriadi, "Sistem Pakar Diagnosa Gangguan Kecemasan Menggunakan Metode Certainty Factor," vol. 02, no. 02, pp. 13-23, 2020.

[4] F. Farajullah and M. Murinto, "Sistem Pakar Deteksi Dini Gangguan Kecemasan (Anxiety) Menggunakan Metode Forward Chaining Berbasis Web," JSTIE (Jurnal Sarj. Tek. Inform., vol. 7, no. 1, p. 1, 2019, doi: 10.12928/jstie.v7i1.15800.

[5] A. E. S. Putri Barka; Seniwati, Erni, "Implementasi Metode Forward Chaining Pada Sistem Pakar Pendiagnosis Gangguan Ansietas (Studi Kasus: Pijar Psikologi)," J. Mantik Penusa, vol. 2, no. Vol 2, No 2 (2018): Computer Science, pp. 9-14, 2018, [Online]. Available: http://ejurnal.pelitanusantara.ac.id/index.php/mantik/article/view/369.

[6] D. Eridani, M. Aditya, M. Rifki, and R. Rizal, "Sistem Pakar Pendiagnosis Gangguan Kecemasan Menggunakan Metode Forward Chaining Berbasis Android," Edu Komputika J., vol. 5, no. 1, pp. 62-68, 2018, doi: 10.15294/edukomputika.

[7] N. E. Saragih and R. Adawiyah, "JURNAL MEDIA INFORMATIKA BUDIDARMA Penerapan Metode Dempster Shafer Untuk Sistem Deteksi Gangguan Kecemasan Obsessive Compulsive Disorder Berbasis Web," vol. 5, no. 1, pp. 48-57, 2021, doi: 10.30865/mib.v5i1.2533.

[8] I. M. Puspita, A. W. Rozifa, and A. M. Nadhiroh, "Gambaran Kecemasan Dan Kepatuhan Remaja Putri Terhadap Kebiasaan Baru Di Masa Pandemi Covid-19," JOMIS (Journal Midwifery Sci., vol. 5, no. 1, pp. 5261, 2021, doi: 10.36341/jomis.v5i1.1492.

[9] M. K. Remaja, “Jurnal Keperawatan," vol. 13, pp. 81-90, 2021.

[10] R. M. Candra, B. Mirwanto, T. Informatika, U. Islam, N. Sultan, and S. Kasim, "Sistem Pakar Untuk Mendiagnosa Gangguan Anxietas Dengan Menggunakan Teorema Bayes," vol. 4, no. 2, 2018.

[11] D. W. T. Putra and R. Andriani, "Unified Modelling Language (UML) dalam Perancangan Sistem Informasi Permohonan Pembayaran Restitusi SPPD," J. TeknoIf, vol. 7, no. 1, p. 32, 2019, doi: 10.21063/jtif.2019.v7.1.32-39. 